\title{
Evaluation of Newly Released Improved Haricot Bean (Phaseolus vulgaris L.) Varieties Under Smallholder Famers' Condition in Metekel Zone, Northwestern Ethiopia
}

\author{
Takele Atnafu Delele ${ }^{1 *}$, Dirshaye Hailu Gebre, Yaregal \\ Fekadu Simachew $^{1}$ \\ 1.Department of Agricultural Extension and Communication Research, Ethiopian Institute of Agricultural \\ Research, Pawe Agricultural Research Center, P. O. Box, 25, Pawe, Ethiopia
}

\begin{abstract}
Ethiopia has favorable agro ecologies for haricot bean production. The people habitually consume it besides serve as a cash crop across the country. The current production status is not comparable to the existing market and consumption needs coupled with low productivity due to absence of improved haricot bean varieties. This study focused on evaluation of newly released improved haricot bean varieties under smallholder farmers' condition in Metekel Zone. The evaluation was done in Debate and Mandura districts due to their potential. Five kebeles and 22 hosted farmers were selected purposively based on their experience and willingness to implement the demonstration. SER-119, SER-125 and NASIR varieties were the materials used for evaluation. Each participant farmer provided a $25 \mathrm{~m} * 25 \mathrm{~m}\left(625 \mathrm{~m}^{2}\right)$ plot of land for each variety. Both qualitative and quantitative data were collected from 42 farmers (20 control group) through appropriate data collection tools. The data were analyzed through descriptive and inferential statistics using SPSS (version 26) software package. Farmers' preference ranking also carried out accordingly based their own criteria. Marketability, grain yield, seed color, maturity date, pod number per plant and disease resistance were the main preference traits for famers. Results show the highest (1303.55 $\left.\mathrm{kg} \mathrm{ha}^{-1}\right)$ mean grain yield observed from SER-119 variety in all testing sites. Although yield variability observed among the varieties, all the evaluated improved varieties have significant yield increment over the control at $(\mathrm{p}<0.01)$. The highest net return $\left(16,539.19 \mathrm{ETB}^{-1} \mathrm{ha}^{-1}\right)$ received from SER119. Findings revealed that SER-119 and SER-125 dominated NASIR variety particularly regarding grain yield and preferred varieties by farmers. Therefore, farmers have been encouraged to use the preferred varieties accordingly for large-scale production with close guidance of development agents and experts.
\end{abstract}

Keywords: Demonstration, Farmers' preference, Haricot Bean, Metekel and Varieties

DOI: $10.7176 / \mathrm{JNSR} / 12-20-04$

Publication date:October $31^{\text {st }} 2021$

\section{Introduction}

Haricot bean is one of the major pulse crops grown widely in the world. Haricot bean positively contributed to improve the nutritional composition of balanced health diets due to its high protein content and micro-nutrient concentration(Worku, 2015). Ethiopia has favorable agro ecology for legume crop production(Kebede, 2020). In terms of grain yield and production coverage, faba bean, haricot bean, field peas and chickpea are the four leading legumes in the country. Haricot bean is the most important food legume for direct human consumption as well as for international market to earn foreign currencies(Yokamo and Wotro, 2018). Haricot beans are among the most important grain legumes produced by small-scale farmers for both subsistence and cash mainly in the lowlands and in the rift valley areas of Ethiopia(Lemu, 2016). It is one of the lowland pulse crops produced in different parts of Ethiopia. It has been known as an export crop for long period of time contributing to the foreign exchange earning of the country. Ethiopia produced 540,238.94 tons of haricot beans by cultivating 357,299.89 hectare land during 2016 plating season(Demelash, 2018). The national average yield of haricot bean during 2015/16 cropping season is about $1485 \mathrm{~kg}$ per hectare(Cochrane and Bekele, 2018). Low production and productivity is the main problem for Ethiopia due to low level of adoption of improved haricot bean technologies, poor agronomic and marketing systems(Amanuel and Girma, 2018). Haricot bean is considered as the main cash crop and protein source of farmers in many low lands and mid altitude zones of Ethiopia(Beyene et al., 2020).

The country's export earnings from haricot bean exceed that of other pulses such as lentils, horse bean and chickpea. Ethiopia got 134 million USD from export earnings of haricot bean in 2014(Lemu, 2016). According the results of this study, Oromia, Southern Nation Nationality and Peoples' of Ethiopia (SNNP), Amhara and Benishangul Gumuz are the main haricot bean producing areas and these regions contributed $99 \%$ output in the country. It is also one of the major grain legumes widely cultivated by the smallholder farmers in the Southern Nation, Nationalities and Peoples of Ethiopia. Haricot bean is an important traditional pulse in Ethiopia particularly in the Southern region of Gamo gofa and Konso districts. It is a basic component of cropping systems of small-scale farmers and diets of people of Ethiopia as in many other countries in east, central and 
southern Africa. Lack of improved seeds, diseases and pests, improper seed distribution channels and poor marketing system were the major constraints of haricot bean production(Rodríguez De Luque and Creamer, 2014). Limited access to improved seeds, low level of production, poor product quality, scattered and fragmented suppliers and high transaction costs negatively contributed for haricot bean value chains(Lemu, 2016).

Metekel and the region have untapped potential on legume crops like haricot bean. The crop is producing in all parts of the region. Haricot bean habitually consuming by most of the peoples of Metekel and the region although productivity is the main challenge in the area. To overcome the problem of low yield of the crop per hectare, Pawe agricultural research center has been conducted adaptation trial on different varieties of haricot bean in close collaboration with Melkasa agricultural research center. The promising varieties recommended using for large-scale production by farmers after the trail has been completed. The recommended varieties were evaluated under smallholder famers' condition through on-farm demonstration before recommending to largescale production. The main objective of this on-farm experimentation is to evaluate the performance of the recently released haricot bean varieties under stallholder farmers' condition further to confirm the preferred variety/ies for large-scale production.

\section{Materials and Methods}

2.1 Description of the study area

The evaluation was carried out in Debate and Mandura districts of Metekel zone due to their potentials in haricot bean production. Metekel zone which is one the three administrative zones of Benishangul Gumuz and has seven districts with three agro ecologies i.e. Kola, Woynadega and Dega. The area receives an average annual rainfall and temperature ranges from 600 to $1540 \mathrm{~mm} / \mathrm{y}$ and 12 to $41^{\circ} \mathrm{C}$ respectively. The altitude ranges from 580 to 2730 m.a.s.l. It has a total population of 470,684 off which 233,040 is males and 237,644 are females. More than $98 \%$ of the rural population depends on agriculture and $95 \%$ of them are living in the rural areas. Maize, sorghum, soybean, sesame, groundnut and haricot bean are the major crops producing in Metekel zone.

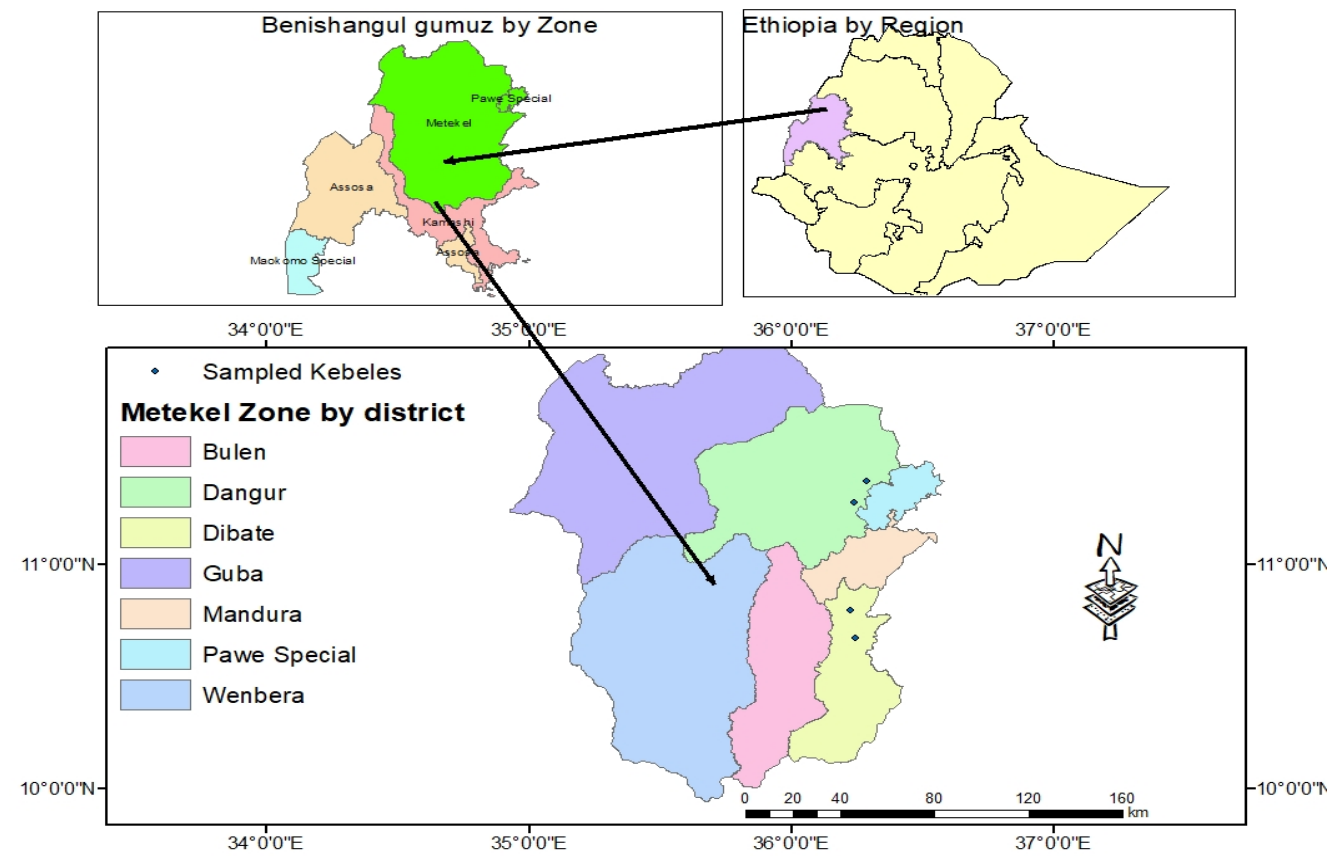

Figure 1. Map of the study area (Metekel Zone)

\subsection{Farmer's selection and field establishment}

Debate and Mandura districts were selected purposively under Metekel zone due to their haricot bean potential. Kebeles and hosted farmers were selected carefully from each district with the help of development agents and experts by considering the performance and willingness to implement the demonstration. Hosted farmers were responsible to manage the demonstration and allocating a $25 \mathrm{~m}^{*} 25 \mathrm{~m}\left(625 \mathrm{~m}^{2}\right)$ plot of land. Three kebeles (Kutir 1, Kutir 2 and Zigih) from Debate district and Etsitsa and Adida kebeles from Mandura district were used for this evaluation. A total of 22 hosted farmers were involved in the demonstration. Additionally, 20 farmers who are producing haricot bean by using the locally available seeds were used as a control group for this evaluation. Pawe agricultural research center provided technical trainings and other technology packages for haricot bean production. NASIR, SER-119 and SER-125 were the varieties used in the demonstration and compared to the 
performance of the local variety as a control. Theoretical and practical trainings were provided to hosted farmers and experts regarding production management and marketing before implementing the demonstration. Farmers were planted the plants with the raw and plant spacing of $40 \mathrm{~cm}$ and $10 \mathrm{~cm}$ respectively by using a seed rate of $100 \mathrm{~kg}$ per hectare. Although planting date varies across regions and districts due to agro ecology variability, Debate and Mandura districts recommended to plant haricot bean starting from end of July to 20 August. Researchers and agricultural experts were arranged a monitoring and evaluation program and performed the tasks accordingly. Advices and correcting actions were given to hosted farmers on the spot at different stages of the crop. Data were recorded and feedbacks collected at each site visit and discussion on the field with farmers and experts.

\subsection{Data collection and analysis}

Both qualitative and quantitative data were collected from 42 farmers (20farmers control) through appropriate data collection tools. Data were collected by the researchers and development agents directly on the demonstrated fields and homestead of farmers. Farmers were organized in to groups to prefer their own variety for further large scale-production based on their own set of criteria. Farmers' preference was recorded carefully during discussion with development agents and experts. The data were analyzed through descriptive and inferential statistics by using SPSS (version 26) software package. Farmers' preference ranking also done based on the criteria set by farmers themselves during evaluation.

\section{Results and Discussion}

\subsection{Capacity building training}

Trainings were given on haricot bean production and management with full recommended packages to 22 hosted farmers and 12 development agents from Debate and Mandura districts for those who are working on the demonstration sites. Both theoretical and practical trainings were provided and different gaps were identified by the researchers at the time of visit. Field level training was also given by grouping farmers in to small groups and discussion with the raised issues to fill the observed gaps.

\subsection{Yield performance}

The results of the evaluation showed that $1348.64,1214.84$ and $1130.44 \mathrm{~kg} \mathrm{ha}^{-1}$ mean grain yield recorded from SER-119, SER-125 and NASIR varieties respectively in Debate district. The maximum grain yield $(1776.4 \mathrm{~kg}$ $\mathrm{ha}^{-1}$ ) was recorded from SER-119 haricot bean variety followed by SER-125 (1504.00 kg ha-1). Even the highest mean grain yield recorded from SER-119 variety which is $1348.64 \mathrm{~kg} \mathrm{ha}^{-1}$. The least mean grain yield (722.65 $\mathrm{kg} \mathrm{ha}^{-1}$ ) observed from the local check variety. Although mean grain yield variability observed among varieties and hosted farmers, the improved ones brought good and acceptable yield as compared to the local seeds. Overall evaluation of the on-farm demonstration indicates that all the demonstrated improved varieties dominated the locally available seeds regarding mean grain yield.

Table 1. Mean grain yield of haricot bean in $\mathrm{kg} \mathrm{ha}^{-1}$ at Debate district

\begin{tabular}{lllll}
\hline Variety & Minimum & Maximum & Mean & Std. Deviation \\
\hline SER-119 & 940.00 & 1776.40 & 1348.64 & 201.27 \\
SER-125 & 973.00 & 1504.00 & 1214.84 & 117.18 \\
NASIR & 800.00 & 1375.00 & 1130.44 & 138.50 \\
Local & 664.00 & 760.40 & 722.65 & 31.26 \\
\hline
\end{tabular}

Source: Own computation from data, 2020

The results depicted in Table 2 indicated that 1249.44, 1133.53 and $920.93 \mathrm{~kg} \mathrm{ha}^{-1}$ mean grain yield recorded from SER-119, SER-125 and NASIR varieties respectively in Mandura district. The maximum grain yield (1440.00 kg ha-1) was recorded from SER-119 variety followed by SER-125 (1363.00 kg ha-1) variety which is a similar result observed from Debate district testing sites. The highest mean grain yield also observed from SER-119 variety which is $1249.44 \mathrm{~kg} \mathrm{ha}^{-1}$. The least mean grain yield $\left(701.77 \mathrm{~kg} \mathrm{ha}^{-1}\right)$ observed from the local check variety. Similarly, all the demonstrated improved varieties dominated the locally available seeds regarding mean grain yield in Mandura district as Debate.

Table 2. Mean grain of haricot bean in $\mathrm{kg} \mathrm{ha}^{-1}$ at Mandura district

\begin{tabular}{lllll}
\hline Variety & Minimum & Maximum & Mean & Std. Deviation \\
\hline SER-119 & 1148.00 & 1440.00 & 1249.44 & 76.30 \\
SER-125 & 900.00 & 1363.00 & 1133.53 & 121.11 \\
NASIR & 722.00 & 1160.00 & 920.93 & 126.20 \\
Local & 500.00 & 754.00 & 701.77 & 74.56 \\
\hline
\end{tabular}

Source: Own computation from data, 2020

The combined analysis over the testing locations revealed that the mean grain yield of all the evaluated 
improved varieties have significant yield increment over the control local variety. As indicated in Table 3 , the combined mean grain yield of $1303.55,1177.88$ and $1035.21 \mathrm{~kg} \mathrm{ha}^{-1}$ recorded from SER-119, SER-125 and NASIR varieties respectively. Mean grain yield variability observed among the varieties across locations. As the combined data indicated in Table 3, the maximum mean grain yield was recorded from SER 119 variety which is $1303.55 \mathrm{~kg} \mathrm{ha}^{-1}$. The combined result showed that all the demonstrated improved varieties performed very well in all testing locations as compared to the locally available seeds. Among the demonstrated improved varieties, SER-119 and SER-125 dominated NASIR variety regarding mean grain yield in all the testing sites. Most farmers preferred this variety in most locations regarding its mean grain yield. This result is in line with (Fistum et al., 2020) who confirmed that the yield of SER 119 and SER 125 varieties dominated NASIR variety. This indicates that yield of haricot bean per hectare significantly increased through use of improved varieties. The findings of (Abele and Tefera, 2015) also found that seed significantly influenced the level of haricot bean production. The finding is consistent with (Siri et al., 2016) who confirmed that productive and disease resistance haricot bean varieties are the most preferred traits by farmers.

Table 3. Combined mean yield of haricot bean demonstration in $\mathrm{kg} \mathrm{ha}^{-1}$

\begin{tabular}{lllll}
\hline Variety & Minimum & Maximum & Mean & Std. Deviation \\
\hline SER-119 & 940.00 & 1776.40 & 1303.55 & 162.08 \\
SER-125 & 900.00 & 1504.00 & 1177.88 & 123.27 \\
NASIR & 722.00 & 1375.00 & 1035.21 & 168.15 \\
Local & 500.00 & 760.40 & 712.21 & 56.67 \\
\hline
\end{tabular}

Source: Own computation from data, 2020

\subsection{Statistical test}

The results depicted in Table 4 showed that the newly released haricot bean varieties had significant yield increment over the control local variety in all testing sites. The respective mean grain yield of 1172.21 and $712.21 \mathrm{~kg} \mathrm{ha}^{-1}$ recorded from improved seed users and non-users. The result of t-test $(\mathrm{t}=-14.41, \mathrm{p}<0.01)$ is an evidence for the existence of statistical mean difference between improved seed users and non-users regarding grain yield. The negative sign of t-value (-14.41) implies that those farmers who use local haricot bean seeds produce less output as compared to their counter parts. The result agrees with (Tadesse et al., 2014) who confirmed that lack of access to improved haricot bean varieties significantly reduced productivity. The result is also in line with (Fistum et al., 2020) who found that the improved SER-119 and SER-125 varieties have better yield advantage over the control local variety. This finding also consistent with (Tarekegn and Mogiso, 2020) who showed that improved seeds are the key input to increase crop productivity. Findings of this study suggest that $35 \%$ yield loss per hectare observed due to use of locally available seeds. Use of improved seeds positively correlated to productivity (Meughoyi, 2018). According to the findings of this study, $0.351 \mathrm{~kg} \mathrm{ha}^{-1}$ productivity gap observed between improved maize seed users and non-users.

Table 4. Statistical test of improved seed users and non-users regarding mean grain yield

\begin{tabular}{|c|c|c|c|c|c|c|}
\hline \multirow[b]{2}{*}{ Variable } & \multicolumn{6}{|c|}{ Grain yield in kg per ha } \\
\hline & Category & Frequency & Mean & $\mathrm{SD}$ & t-value & Sig. value \\
\hline \multirow[t]{2}{*}{ Improved seed } & Non-users & 20 & 712.21 & 56.67 & -14.41 & 0.000 \\
\hline & Users & 22 & 1172.21 & 132.03 & & \\
\hline
\end{tabular}

Source: Own computation from data, 2020

3.4 Yield gap and advantage

The results of the evaluation depicted in Table 5 showed that all the demonstrated improved variety seeds had significant yield advantage over the control in all testing sites. The maximum yield increment observed from SER-119 variety both in Debate and Mandura districts followed by SER-125 variety. Yield advantage of 625.99 and $547.67 \mathrm{~kg}$ was recorded from SER-119 and SER-125 in Debate and Mandura districts respectively. The least yield increment over control observed from NASIR variety in both districts. Farmers primarily selected SER-119 and SER-125 varieties due their significant yield advantage and requested seeds for large-scale production. 
Table 5. Mean yield increment of improved haricot bean varieties over control in $\mathrm{kg} \mathrm{ha}^{-1}$

\begin{tabular}{|c|c|c|c|c|c|c|c|}
\hline Location & Variety & Minimum & Maximum & Mean & $\begin{array}{l}\text { Control } \\
\text { yield }\end{array}$ & $\begin{array}{l}\text { Yield } \\
\text { increment } \\
\text { over } \\
\text { control }\end{array}$ & $\begin{array}{l}\text { Std. } \\
\text { Deviation }\end{array}$ \\
\hline \multirow[t]{3}{*}{ Debate } & SER-119 & 940.00 & 1776.40 & 1348.64 & 722.65 & 625.99 & 201.27 \\
\hline & SER-125 & 973.00 & 1504.00 & 1214.84 & 722.65 & 492.19 & 117.18 \\
\hline & NASIR & 800.00 & 1375.00 & 1130.44 & 722.65 & 407.79 & 138.50 \\
\hline \multirow[t]{3}{*}{ Mandura } & SER-119 & 1148.00 & 1440.00 & 1249.44 & 701.77 & 547.67 & 76.30 \\
\hline & SER-125 & 900.00 & 1363.00 & 1133.53 & 701.77 & 431.76 & 121.11 \\
\hline & NASIR & 722.00 & 1160.00 & 920.93 & 701.77 & 219.16 & 126.20 \\
\hline
\end{tabular}

Source: Own computation from data, 2020

\subsection{Financial benefits}

The results indicated in Table 6 revealed that farmers received good net returns from improved haricot bean varieties due to significant yield advantage over the control. Average selling price of haricot bean was 18.09 ETB per kilogram during 2020 marketing season as data collected from hosted farmers and control group by triangulating with local and district traders. Farmers got a gross return of 18,726.93, 23,581.19 and 21,296.00 ETB per hectare from NASIR, SER-119 and SER-125 varieties respectively within that particular marketing season. The highest gross return observed from SER-119 variety followed by SER-125. Similarly, the highest net return $\left(16,539.19 \mathrm{ETB} \mathrm{ha}^{-1}\right)$ received from SER-119 variety by incurring a production cost of 7042 ETB. The $2^{\text {nd }}$ good net return $\left(14,254 \mathrm{ETB} \mathrm{ha}^{-1}\right)$ received from SER-125 variety. Farmers also received 11,684.93 $\mathrm{ETB}^{-1}$ net returns from NASIR variety. The least net return (6241.91 ETB ha $\mathrm{E}^{-1}$ ) observed in the local control variety. Findings of this evaluation suggest farmers encouraged using improved variety seeds to get better net return as compared to local seeds. The finding agrees with (Sime and Aune, 2018) who found the existence of positive correlation of using improved varieties and improvement of food security and farmers' income.

Table 6. Net benefit return received from haricot bean varieties

\begin{tabular}{|c|c|c|c|c|}
\hline \multirow[b]{2}{*}{ Category } & \multicolumn{3}{|c|}{ Varieties } & \multirow[b]{2}{*}{ Local seed } \\
\hline & NASIR & SER-119 & SER-125 & \\
\hline Mean grain yield $\left(\mathrm{kg} \mathrm{ha}^{-1}\right)$ & 1035.21 & 1303.55 & 1177.88 & 712.21 \\
\hline Production cost $\left(\mathrm{ETB} \mathrm{ha}^{-1}\right)$ & 7042.00 & 7042.00 & 7042.00 & 6642.00 \\
\hline Selling price $\left(\mathrm{ETB} \mathrm{ha}^{-1}\right)$ & 18.09 & 18.09 & 18.08 & 18.09 \\
\hline Gross return $\left(\mathrm{ETB} \mathrm{ha} \mathrm{ha}^{-1} 1\right)$ & 18726.93 & 23581.19 & 21296.00 & 12883.91 \\
\hline Net return $\left(\mathrm{ETB} \mathrm{ha}^{-1}\right)$ & 11684.93 & 16539.19 & 14254.00 & 6241.91 \\
\hline
\end{tabular}

$\mathbf{E T B}=$ Ethiopian Birr, ha $=$ hectare

3.6 Farmers' preference of improved varieties

The demonstrated improved varieties were evaluated during field day events besides evaluated at different stages of the crop in both districts. During evaluation, 55 farmers were directly involved and 49.09\% of them selected SER-119 variety in Debate district. SER-125 variety was selected by $38.18 \%$ of participants and NASIR was the last choice of farmers. Similarly, 57 farmers were participated in the evaluation and most $(54.39 \%)$ of the participants selected SER-119 in Mandura district followed by SER-125 variety. Marketability, mean grain yield, seed color, maturity date, number of pods per plant and disease resistance was the main preference traits for farmers in this evaluation. The finding by (Siri et al., 2016) also showed that early maturity, high yielder, pest and disease resistance were the main preference traits for farmers to choose their own best haricot bean variety. The preference of farmers was based on the total score of the traits. SER-119 variety was primarily preferred in all testing locations based on the cumulative score as indicated in Table 7. SER-119 variety scored the maximum point in most of the traits. SER-125 secondly preferred next to SER-119 in both districts. Overall, although farmers have their own preference traits based on their own selection criteria, all the demonstrated improved varieties had significant yield advantage over the control. The finding by (Kebede et al., 2018) showed that market demand, early maturity, disease and pest resistance, drought tolerance and others were the preference traits for farmers to choose improved haricot bean varieties. 
Table 7. Farmers' preference traits of improved haricot bean varieties in the two districts

\begin{tabular}{|c|c|c|c|c|c|c|c|c|c|c|}
\hline & & & & $\begin{array}{l}\text { Preference } \\
\text { traits }\end{array}$ & & & & & & \\
\hline Location & $\begin{array}{l}\text { Variety } \\
(\mathrm{N}=55)\end{array}$ & NFCV & Marketability & Grain yield & $\begin{array}{l}\text { Seed } \\
\text { color }\end{array}$ & $\mathrm{DM}$ & PNPP & DR & $\begin{array}{l}\text { Total } \\
\text { score }\end{array}$ & Rank \\
\hline \multirow[t]{3}{*}{ Debate } & SER-119 & $\begin{array}{l}27 \\
(49.09)\end{array}$ & 3 & 4 & 2 & 4 & 3 & 2 & 18 & $1^{\text {st }}$ \\
\hline & SER-125 & $21(38.18)$ & 3 & 3 & 2 & 3 & 3 & 2 & 16 & $2^{\text {nd }}$ \\
\hline & NASIR & $7(12.73)$ & 3 & 2 & 2 & 2 & 2 & 1 & 12 & $3^{\mathrm{rd}}$ \\
\hline \multirow[t]{4}{*}{ Mandura } & $(\mathrm{N}=57)$ & & & & & & & & & \\
\hline & SER-119 & $\begin{array}{l}31 \\
(54.39)\end{array}$ & 2 & 4 & 2 & 3 & 3 & 3 & 17 & $1^{\text {st }}$ \\
\hline & SER-125 & $18(31.58)$ & 2 & 3 & 2 & 3 & 3 & 3 & 16 & $2^{\text {nd }}$ \\
\hline & NASIR & $8(14.04)$ & 2 & 1 & 2 & 2 & 1 & 1 & 9 & $3^{\text {rd }}$ \\
\hline
\end{tabular}

$\mathrm{DM}=$ days of maturity, $\mathrm{DR}=$ disease resistance, $\mathrm{NFCV}=$ number of farmers choose the variety, PNPP $=$ pod number per plant

\section{Conclusion and Recommendation}

The findings of this study concluding farmers were not benefited as well from haricot bean production due to low productivity of locally available seeds. Lack of access to improved haricot bean varieties with other recommended full packages negatively and significantly contributed crop productivity and that is why the expected return cannot be received as compared to the existing potential. Findings suggest that SER-119, SER125 and NASIR variety well performed in all locations and have significant yield advantage over the control local seeds. The highest mean grain yield observed from SER-119 variety both in Debate and Mandura districts. The maximum net return also received from SER-119 due to its high mean grain yield. Marketability, grain yield, maturity date, seed color, pod number per plant and disease resistance were the preference traits for farmers in the study area. Although grain yield was put as the main preference trait by most of the farmers, the final selection is based on the total score given to each trait of the varieties. Improved varieties particularly SER-119 and SER-125 were primarily selected by most of the farmers in all the testing sites. Therefore, each district and Zone agricultural offices have to promote these varieties accordingly and multiply the seeds with concerned bodies to ensure availability of selected seeds for large-scale production.

\section{References}

Abele, W. \& Tefera, T. (2015). Factors Affecting Production and Market Supply of Haricot Bean in Southern Ethiopia. Journal of Economics and Sustainable Development 6(15): 103-109.

Amanuel, A. \& Girma, A. (2018). Production status, adoption of improved common bean (Phaseolus vulgaris L.) varieties and associated agronomic practices in Ethiopia. J Plant Sci Res 5(1): 178.

Beyene, T., Mulugeta, W. \& Merra, T. (2020). Technical efficiency and impact of improved farm inputs adoption on the yield of haricot bean producer in Hadiya zone, SNNP region, Ethiopia. Cogent Economics \& Finance 8(1): 1833503.

Cochrane, L. \& Bekele, Y. W. (2018). Average crop yield (2001-2017) in Ethiopia: Trends at national, regional and zonal levels. Data in brief 16: 1025.

Demelash, B. (2018). Common Bean Improvement Status (Phaseolus vulgaris L.) in Ethiopia. Adv. Crop. Sci. Tech 6: 347.

Fistum, M., Gemechu, G. \& Belay, R. (2020). Evaluation of newly released common bean varieties through onfarm demonstrations in ATJK and Shalla districts of Oromia regional state, Ethiopia. Int. J. Res. Stud. Agric. Sci 6(1): 43-48.

Kebede, B., Korji, D. \& Amare, G. (2018). Participatory Evaluation and Selection of Improved Haricot bean Varieties at Liben District, Lowland Agro Ecology of Guji Zone, Oromia Regional State, Ethiopia. $A d v$ Crop Sci Tech 6(332): 2.

Kebede, E. (2020). Grain legumes production and productivity in Ethiopian smallholder agricultural system, contribution to livelihoods and the way forward. Cogent Food \& Agriculture 6(1): 1722353.

Lemu, E. T. (2016). Review of haricot bean value chain in Ethiopia. International Journal of African and Asian Studies 24: 65-72.

Meughoyi, C. T. (2018).Improved seeds and agricultural productivity of family farms in Cameroon. In Building a Resilient and Sustainable Agriculture in Sub-Saharan Africa, 15-32: Palgrave Macmillan, Cham.

Rodríguez De Luque, J. J. \& Creamer, B. (2014). Principal constraints and trends for common bean production 
and commercialization; establishing priorities for future research. Agronomia colombiana 32(3): 423-431.

Sime, G. \& Aune, J. B. (2018). Sustainability of improved crop varieties and agricultural practices: A case study in the Central Rift Valley of Ethiopia. Agriculture 8(11): 177.

Siri, B., Etchu, K., Manka, S., Emoh, S., Atemkeng, M. \& Nounamo, L. (2016). Assessing Preference of Released Improved Haricot Bean (Phaseolus Vulgaris L.) by Farmers in the Western Highland of Cameroon. Int. J. Dev. Res 6(7): 8317-8322.

Tadesse, D., Alem, T., Wossen, T. \& Sintayehu, A. (2014). Evaluation of improved varieties of haricot bean in West Belessa, Northwest Ethiopia. International Journal of Science and Research (IJSR) 3: 2756-2759.

Tarekegn, K. \& Mogiso, M. (2020). Assessment of improved crop seed utilization status in selected districts of Southwestern Ethiopia. Cogent Food \& Agriculture 6(1): 1816252.

Worku, W. (2015). Haricot bean production guide: With emphasis on southern Ethiopia. Scalingup Pulse Innovations for Food and Nutrition Security in Southern Ethiopia which is supported by the Canadian International Food Security Resear. DOI: HYPERLINK" https://www. researchgate. net/deref/http\% $3 A \%$ $2 F \% 2 F d x$. doi. org\% $2 F 1013140$.

Yokamo, S. \& Wotro, W. (2018). Pre Extension Demonstration of Improved Common Bean Phaseolus Vulgaris with its Full Packages in Gamogofa and Segen Area Peoples Zone, SNNPRs, Ethiopia. International Journal of Environmental Sciences \& Natural Resources 13(4): 102-107. 